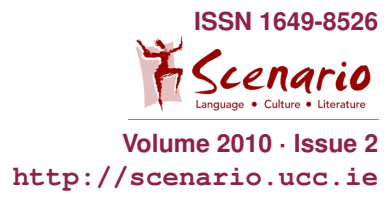

TaT - Texts around Theatre - TaT

\title{
Paul the Puppeteer
}

\section{Theodor Storm}

Theodor Storm's novella, Paul the Puppeteer (1874), is a touching children's story. Little Paul experiences a puppet show in his village. He is enthralled by the puppets. He makes friends with Lisei, the daughter of the travelling puppeteers, who is about his age. Through Lisei he can clandestinely visit the puppets. Although Lisei beseeches him not to touch them, Paul cannot help himself and pulls on the strings of the Kasperle-puppet. While he is engrossed in his play, something breaks inside Kasperl. Paul is now haunted by a guilty conscience, and is very anxious when he goes to the staging of "Faust" the next day, since Kasperle plays an important part in the story. Paul is not the only one who is anxious and tense, but also Lisei's parents, because the success of the evening depends on their ability to limit the damage by artful improvisation.

Seven o'clock had struck; all the seats in the Schützenhof were full today, Sunday; I was standing at the back this time, some five feet above the floor, in the two-schilling area. The tallow candles were burning in the metal lanterns, the towns' music director and his three apprentices were playing their violins; the curtain rose.

A high-vaulted gothic chamber appeared. Doctor Faust sat in a dark ankle-length gown in front of an opened folio volume, complaining bitterly that his learning earned him so little, not even a decent coat to his back; at a loss what to do because of debts, he was now going to join with the forces of Hell. - „Who calls for me?" sounded a terrifying voice from the vault of the room to his left. „Faust, Faust, don't go!“ came another, gentler voice from the right. But Faust has conspired with the forces of Hell. - „Woe, woe, unto your pour soul!“ The angel's voice sounded like a dying breath of wind; from this left a shriek of laughter resounded across the chamber. - There was a knock at the door. „Excuse me, Your Magnificence.“Faust's famulus, Wagner, entered. He asked to be allowed to engage the services of a helper for the burdensome housework so that he could better concentrate on this studies. „A young man came to see me," he said, „by the name of Kasperl, who seemed to possess excellent qualities." Faust graciously nodded his head and said: „Very well, my dear Wagner, your request is granted. Then they left the chamber together.

"Whoops!" came the cry; and there he was. With a leap he jumped onto the stage, and his knapsack bounced on his back. 
„God be praised!“ I thought. „He's still all right; he jumps just as he did last Sunday in the fair Genovieve's castle!" And it was strange, however much he had appeared in my thoughts that morning as just a pathetic wooden puppet, with the first word he uttered, the whole magic was there again.

He bustled up and down the room. „If my father could see me now, “ he cried, „he'd surely be pleased. He always used to say: ,Kasperl, see you put a swing into iti And now it's got a swing; I can swing it as high as the roof top!"With that he pulled a face and slung his knapsack into the air; and it really flew, for it was pulled by wires, right up into the roof vaulting; but - Kasperl's arms were glued to his sides; there was pulling and tugging, but they didn't lift an inch. Kasperl just spoke and did nothing more. There was a commotion backstage, low but angry voices were heard, the flow of the play was obviously interrupted. My heart stood still; it jsut had to happen! I would willingly have run away, but I was ashamed. And if something should happen to Lisei because of me!

Then Kasperl, with his head and arms hanging limply down, suddenly let out a pitiful howl on the stage, at which Wagner reappeared and asked him what he was wailing about.

"Oh, my tooth, my tooth!" howled Kasperl.

"Good friend,“ said Wagner, „let me take a look in your mouth!" And as he seized him by his huge nose and peered between his jaws, Doctor Faust too came back into the chamber.

„Your humble pardon, Your Magnificence,“ said Wagner, „but I'm not able to take this young man into my service; he must be taken to an infirmary immediately!"

„Is that an inn?" asked Kasperl.

„No, good friend,“ replied Wagner, „it's a slaughterhouse. They'll cut a wisdom tooth out of your head there, then your pain will be gone."

„Oh, dear God!“ moaned Kasperl. „Must such a terrible thing happen to a poor creature like me! A wisdom tooth, you said, Herr Wagner? No one's had that in the family before! Then it could even bring my Kasperlship to an end?"

"Certainly, my friend,“ said Wagner. „A servant with wisdom teeth I can well do without; these things are only for us learned folk. But you've got a nephew who's also applied for service with me. Perhaps, "and he turned towards Doctor Faust, „you will permit it, Your Magnificence!“

Doctor Faust gave a dignified turn of the head.

„Do as you wish, my dear Wagner," he said, „but do not disturb me in my studies of magic any further with your trifles!"

"Just listen to that, my friend," said a tailor's journeyman, who was leaning on the balustrade in front of me, to his neighbour. „Doesn't belong in the piece at all. I know it, saw it not so long ago in Seifersdorf.“

„Shut up, Leipziger!" the other replied, poking him in the ribs.

On the stage, meanwhile, a second Kasperl had entered. He bore an unmistakable likeness to his sick uncle, and even spoke exactly like him; he was simply missing the moving thumb and appeared to have no joint in his large nose. 
When the play continued smoothly I felt as if a stone had been lifted from my heart, and I soon forgot everything around me. The diabolical Mephistopheles appeared in a fiery-red cloak, a small horn on his forehead, and Faust signed the hellish pact with his blood:

"You shall serve me for twenty-four years; then I will be yours, body and soul."

Thereupon they both sped away through the air in the devil's magic cloak.

From: Theodor Storm: Paul the Puppeteer and other short fiction. London: Angel Books (2004), 90-92 